The Indigo Bunting is regarded as a "scarce summer resident" by Salt and Wilk, who list the following records: a male specimen from Lac La Nonne, June 3, 1926; a male seen near Elkwater Lake in the Cypress Hills, June 26, 1952; and specimens from Gorge Creek in the foothills west of Turner Valley, were apparently nesting along with Lazuli Buntings in 1958 and 1959.

\section{UNUSUAL FATAL ACCIDENT INVOLVING A LAPLAND LONGSPUR}

by Spencer G. Sealy, Department of Zoology, University of British Columbia, Vancouver, B.C.

A source of winter income for some Eskimos on St. Law rence Island, Alaska, is trapping arctic foxes (Alopex lagopus) (Hughes, An Eskimo Village in the Modern World, Cornell Univ. Press. 1960). One of the many types of bait used for this purpose is seal fat which is placed in and near the trap site, usually before the trapping season begins, and which is often left after trapping is over (Leroy Kulukhon, pers. comm., 1967). This note records an incident whereby a piece of seal blubber caused or contributed to the death of a Lapland Longspur (Calcarius lapponicus).

On July 19, 1967, a dead and ema-

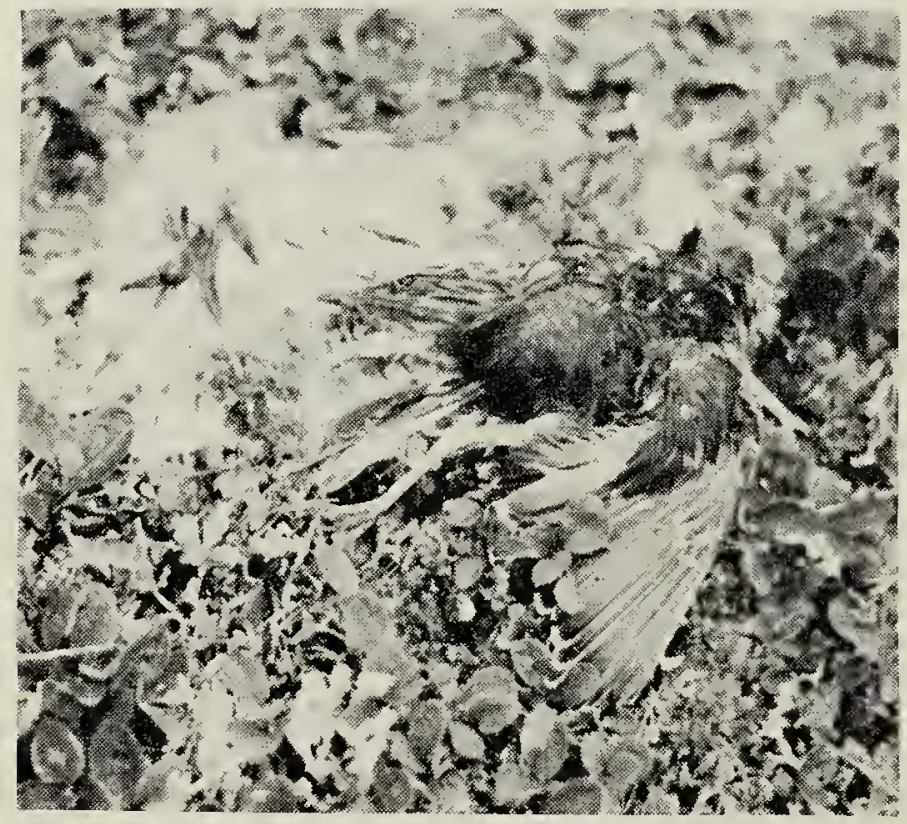

Fig. 1 - Dead and emaciated Lapland Longspur with its left leg s.tuck to a piece of seal blubber, St. Lawrence Island, Alaska, July 19, 1967. ciated Lapland Longspur, its age and sex undetermined, was found at the base of Sevuokuk Mountain, two miles east of Gambell. The bird's left foot was stuck solidly to a piece of seal blubber near an abandoned trap site amid dwarf willows (Salix) (Fig 1), common foraging areas for Lapland Longspurs at this date on S.t. Lawrence Island. The entanglement possibly resulted when the bird accidentally stepped on the fat while foraging or possibly it was attracted to insects on the fat. Insects constitute a large proportion of Lapland Longspur food at this time (Sealy, unpublished data).

Arctic breeding birds face many problems in the short summer; however, unique accidents like that described here probably form a negligible mortality factor. This observation was made while I was engaged in a comparative breeding biology study of the plankton-feeding alcids on St. Lawrence Island. The work was supported by a grant from the National Research Council of Canada to Dr. M. D. F. Udvardy.

\section{AN UNUSUAL GOLDFINCH MORTALITY}

by Ken P. Morrison, Oliver, B.C.

On August 18, 1967 while carrying out an ecology study of the Mourning Dove in the $\mathrm{Okanagan}$ valley of British Columbia, I discovered an unusual incidence of nest mortality in the American Goldfinch (Spinus tristis).

During my routine dove nest search I noticed a small, compact nest 10 feet up in a peach tree in an Oliver orchard. Closer inspection revealed a dead juvenile Goldfinch hanging from the edge of the nest with both feet securely entangled in the plant fiber of the inner lining. The bird had struggled in vain as attested by the frayed and worn feathers of the wings and tail where they had been beaten on the branches supporting the nest. The cause of death was probably due to starvation. The other nestlings appear to have fledged without diffi- 
culty, judging by the numerous droppings and feather sheaths in the nest bowl.

The Goldfinch is an abundant nesting species in the orchards of the Okanagan valley. This is the first occurrence of such an unusual form of mortality in about 30 Goldfinch nests observed this summer.

\section{FIRST RECORD OF LARK BUNTING AND LARK SPARROW AT SPIRIT LAKE, SASKATCHEWAN}

by William Anaka, Gorlitz

On June 2, 1967 a male Lark Bunting (Calamospiza melanocorys) flushed in front of the tractor while I was driving across a native prairie meadow, thereby establishing a new record for Spirit Lake. Dr. C. Stuart Houston's check-list of Birds of the Yorkton district (1949) lists the nearest previous observation from Melville, approximately 50 miles to the south-southwest.

While at the Saskatchewan Natural History Society's summer meeting at Swift Current in June, 1967, I noted that the Lark Bunting was the most conspicuous bird species of the area, as we drove through miles and miles of male buntings, all busily singing and displaying.

Four days later, on June 6, 1967, a new species was added to the birds of the Yorkton district when a Lark Sparrow (Chondestes grammacus) spent an afternoon in our farmyard, alternately feeding and singing. Its conspicuous markings and large size alerted me to its presence as it fed near a number of House Sparrows. The song was even more distinctive, a variety of warbles and trills, occasionally interspersed with a loud buzz. It was noted again on June 20 and June 23 in a nearby pasture field where it sang repeatedly from several locations and behaved as if on territory, at one time aggressively routing a cowbird that ventured near. Lack of additional observations would indicate that it failed to attract a mate and eventually moved on.

In conversation with Dr. Stuart
Houston I have verified that these two birds are new records for these districts.

\section{COWBIRD EGG IN CROW NEST}

by David R. M. Hatch, 736 - 15th St., Brandon, Manitoba

On June 15, 1967 I found a Common Crow nest one-half mile east of the town of Oak Lake, Manitoba, and proceeded to climb the aspen poplar tree in which it was located in order to check the nest contents. To my utter amazement the nest contained a Brown-headed Cowbird egg besides the clutch of five crow eggs. Unfortunately, this nest had been destroyed when I returned to visit it one week later (June 22). The nest site was on the edge of a willow-aspen bluff covering about one-half acre. This was one of a series of bluffs growing in a low area in a heavily grazed pasture. To my knowledge, this is the first occurrence of a cowbird egg being found in a nest of a crow.

\section{ERRATUM}

In the listing of Black-crowned Night Heron recoveries on page 112 of the September 1967 issue, incorrect banding and recovery dates were given for George Lang's seventh Night Heron, shot in Vera Cruz, Mexico. It was banded June 20, 1925 and shot in mid-November of the same year. (The data from the bird above were inadvertently repeated in error).

\section{CHRISTMAS BIRD COUNT 1967}

In your report, list the numbers of each species seen on the $\mathrm{ONE}$ BEST DAY between December 20 and January 1 (inclusive). In addition, list other species (number of individuals and date seen) between December 20 and January 1. Send reports as soon as possible to

MRS. MARY HOUSTON, 863 University Drive, Saskatoon 